IZA DP No. 7049

The Labor Demand Was Downward Sloping: Disentangling Migrants' Inflows and Outflows, 1929-1957

Costanza Biavaschi

November 2012 


\title{
The Labor Demand Was Downward Sloping: Disentangling Migrants' Inflows and Outflows, 1929-1957
}

\author{
Costanza Biavaschi
}

$I Z A$

Discussion Paper No. 7049

November 2012

\author{
IZA \\ P.O. Box 7240 \\ 53072 Bonn \\ Germany \\ Phone: +49-228-3894-0 \\ Fax: +49-228-3894-180 \\ E-mail: iza@iza.org
}

\begin{abstract}
Any opinions expressed here are those of the author(s) and not those of IZA. Research published in this series may include views on policy, but the institute itself takes no institutional policy positions. The IZA research network is committed to the IZA Guiding Principles of Research Integrity.

The Institute for the Study of Labor (IZA) in Bonn is a local and virtual international research center and a place of communication between science, politics and business. IZA is an independent nonprofit organization supported by Deutsche Post Foundation. The center is associated with the University of Bonn and offers a stimulating research environment through its international network, workshops and conferences, data service, project support, research visits and doctoral program. IZA engages in (i) original and internationally competitive research in all fields of labor economics, (ii) development of policy concepts, and (iii) dissemination of research results and concepts to the interested public.
\end{abstract}

IZA Discussion Papers often represent preliminary work and are circulated to encourage discussion. Citation of such a paper should account for its provisional character. A revised version may be available directly from the author. 
IZA Discussion Paper No. 7049

November 2012

\section{ABSTRACT \\ The Labor Demand Was Downward Sloping: Disentangling Migrants' Inflows and Outflows, 1929-1957}

This paper studies in- and out-migration from the U.S. during the first half of the twentieth century and assesses how these flows affected state-level labor markets. It shows that outmigration positively impacted the wages of remaining workers, while in-migration had a negative impact. Hence, immigrant arrivals were substitutes of the existing workforce, while out-migration reduced the competitive pressure on labor markets.

JEL Classification: F22, J01, J61, N32

Keywords: migration flows, impact of migration

Corresponding author:

Costanza Biavaschi

IZA

P.O. Box 7240

53072 Bonn

Germany

E-mail: biavaschi@iza.org 


\section{Introduction}

Numerous studies are devoted to the causes and consequences of immigrant inflows to the U.S. between 1860 and 1924. However, at the turn of the twentieth century much of this migration was actually temporary (Bandiera et al., 2010, Abramitzky et al., 2012). The presence of a sizable outflow of primarily low-skilled migrants (Abramitzky et al., 2012) has important consequences on our understanding of how net migration has affected the U.S. Economic theory predicts that such repercussions ultimately depend on the skill distribution of in-migrants, out-migrants, and natives, their degree of substitutability in production, and the flexibility of capital. The impact of these net flows of migrants on wages in current times remains a widely debated empirical question (e.g., Card, 2001, Borjas, 2003, Ottaviano and Peri, 2012); nonetheless, analyses of such effects in the first half of the 1900s are scarce (e.g., Goldin, 1994). Further, the consequences of foreign-born out-migration on the labor market equilibrium have not been investigated.

By using unexplored information on the yearly flows of foreign-born in- and out-migrants to and from each U.S. state collected between 1929 and 1957, this paper disentangles the impact of net migration by separately assessing how incoming and outgoing foreign-born individuals influenced state-level earnings. The paper adds to the discussion in two ways. First, it separates the components of international net migration, thereby adding foreignborn outflows as a further response to labor market imbalances. ${ }^{1}$ Second, it explores the effects of international mobility in a turbulent - and fairly understudied - time in U.S. history, spanning from the Great Depression, through the Second World War, up to the economic expansion following the conflict. ${ }^{2}$

Although migration flows were relatively small during this period, I find that in-migration slightly hampered state earnings growth, while out-migration released pressure on state labor markets. This finding provides indicative evidence that immigrant arrivals and departures substituted existing workers in the short run. Thus, substantial outmigration could work as a smoothing mechanism of the business cycle, implying that net migration would have only a minor effect on the labor market. This negative and rather small impact of net migration complements the results found for later years (e.g., Card, 2001, Borjas, 2003). There is, therefore, some evidence that the labor demand was downward sloping.

\section{Data}

The Passenger Act (1819) and the Immigration Act (1907) required all vessels entering and leaving the U.S. to provide passenger lists to customs collectors. These data were summarized by the Bureau of Immigration (later Immigration and Naturalization Services, INS) in annual reports. This paper uses unexplored information on the state-level distribution of out-migrants and in-migrants - based on intended permanent residence - from the INS annual reports of 1929-1932, 1934-1936, and 1943-1957. ${ }^{3}$

The analysis relates in- and out-migration rates, that is, the number of in- and out-migrants as a share of the existing population, to per capita state-level private earnings, obtained from the Bureau of Economic Analysis. Additional controls include labor market characteristics (the shares of workers in agriculture, mining, manufacturing, trade, and personal services) and demographic characteristics (the share of black people, the share of people

\footnotetext{
${ }^{1}$ Card (2001) and Borjas (2006) look at natives' responses to net foreign-migration.

${ }^{2}$ A notable complementary study to the present one is Boustan et al. (2010), who analyze the effects of internal mobility on non-movers' labor market outcomes in the 1940s.

${ }^{3}$ Only the total number of migrants by state is available in these reports. Further disaggregation - e.g., by skill level - within state is not available.
} 
aged under 14, 15-45, and over 45 years). These variables were collected from the ICPSR no. 02896 (Haines and ICPSR, 2010). Yearly observations were obtained through linear interpolation.

I construct a balanced panel for the 47 contiguous states (excluding Washington D.C.) for the investigated years. The average per capita earnings over the period in constant terms ${ }^{4}$ was $\$ 3165$ (Table A.1). On average, each state received 3,628 immigrants, while about 695 migrants departed. Further, most workers were employed in the agricultural or manufacturing sectors, while approximately $73 \%$ was in prime age.

\section{Results}

The weak relationship between migration rates and per capita personal earnings shown in the first three columns of Table 1 is unsurprising, because understanding the impact of migration is complicated by the non-random allocation of the migrants. Indeed, state-level characteristics might induce higher in- or out-migration rates, biasing upward the OLS results. As long as such characteristics are time-invariant, this source of endogeneity will be eliminated through differentiation using a standard fixed-effects estimator. However, as in- and out-migrants might be attracted or retained by thriving states, these flows might actually cause changes in state earnings. I adopt an instrumental variable approach to control for this simultaneous causality. That is, at least two variables that determine migration rates but do not determine state-level earnings must be found. I use the five-year lags of in- and out-migration rates. ${ }^{5}$ These instruments rely on the observation that "migration begets migration", and current settlement patterns of immigrants (and leaving patterns of outmigrants) depend on the location decisions of earlier waves, to which past rates are related. Indeed, there is evidence that within five years of arrival immigrants tended to stay in settlement areas determined by previous migration arrivals (Lafortune and Tessada, 2011, Ferrie, 1999). Table A.2 in the Appendix shows the first stage results of the instrumental variable estimation, under different specifications. Across all models, endogeneity and weak identification of the instruments can be rejected at the 5\% significance level. These tests provide evidence of the relevance of these instruments. For the instruments to be valid, however, we also need to assume that wage growth is less persistent than migration rates. ${ }^{6}$

After controlling for the simultaneous causality discussed above, I find that a $1 \%$ change in in-migration (outmigration) rates reduces (raises) private earnings growth by $0.02 \%(0.016 \%)$ over the study period (Table 1$)$. These effects are strongly significant. Notably, point estimates are stable, and adding controls only introduces volatility into the estimation. Additional checks were run to validate these results.

First, the reader should interpret the previous estimates as lower bounds of these effects. In fact, natives might have responded to in- and outflows by relocating their labor or capital across states. Notably, during this period there was an important reallocation of labor: the movement of blacks from southern to northern states, ${ }^{7}$ relocation of white natives from urban to suburban areas (Boustan, 2010), and numerous other internal responses to local labor market shocks (Ferrie, 2006). Second, Bandiera et al. (2010) showed that INS immigration statistics substantially

\footnotetext{
${ }^{4}$ CPI collected from the U. S. Department of Labor, Bureau of Labor Statistics (1984-05-11).

${ }^{5}$ Other lags (up to 10-lag) deliver similar but weaker results because of the reduction in sample size. Additionally, in the spirit of Card (2001) I instrumented current flows using the 1910 or 1920 immigrant shares by state as a predictor of exogenous supply-shifts in immigration flows. This instrument delivers point estimates in line with the one presented in Table 1 . However, the instrument is weak and results based on lagged migration shares were therefore preferred.

${ }^{6} \mathrm{An}$ indication of the validity of this assumption can come from the lag-order selection statistics for the wage growth. At the national level and for each state, all standard lag-order selection statistics (AIC, SBIC, and HQIC) indicated no time dependency of this series. Results available upon request.

${ }^{7}$ The share of blacks' variable introduced into the analysis should capture this phenomenon.
} 
Table 1: Effect of In and Out Migration Rates on Per Capita Private Earnings, at the State Level, 1929-1957.

\begin{tabular}{lrrrcccc}
\hline & OLS & OLS & OLS & IV & IV & IV \\
\hline in $_{\text {it }}$ & $-1.4 \mathrm{E}-03$ & 0.001 & $0.003^{*}$ & $-0.020^{* * *}$ & $-0.021^{* * *}$ & $-0.017^{* *}$ \\
& $(0.002)$ & $(0.002)$ & $(0.002)$ & $(0.007)$ & $(0.008)$ & $(0.009)$ \\
out $_{i t}$ & -0.002 & -0.002 & -0.003 & $0.016^{* *}$ & $0.018^{* * *}$ & $0.017^{* *}$ \\
& $(0.002)$ & $(0.002)$ & $(0.002)$ & $(0.006)$ & $(0.007)$ & $(0.007)$ \\
Time Fixed Effects & Yes & Yes & Yes & Yes & Yes & Yes \\
Labor Market & No & Yes & Yes & No & Yes & Yes \\
Demographics & No & No & Yes & No & No & Yes \\
\hline $\mathrm{N}$ & & & & & & 766 \\
\hline
\end{tabular}

Significance levels: ${ }^{*}: 10 \%,{ }^{* *}: 5 \%,{ }^{* * *}: 1 \%$.

Standard errors in parenthesis are robust for arbitrary heteroskedasticity and clustered at the state level. All regressions weighted by the inverse of the state population (in logs).

Sources: in and out measure in-migration and out-migration rates. See main text for details on the variables used.

underreported in- and outflows between 1892 and 1924. Although this underreporting might be present also in the study period of this paper, no other data source is available for these decades.

Based on the foregoing, I halved the sample to assess the stability of the results (Table A.3). Although the point estimates do change, the results stay within the same confidence interval and thus the conclusions on the effects of migration are unchanged. Point estimates suggest an increasing effect of flows on local labor markets. Finally, Table A.3 excludes the states of the mid-Atlantic region as a further robustness check to assess the sensitivity of the analysis to state-level measurement error and interstate mobility, which was particularly pronounced in these states (Ferrie, 2006). Once again, the results are in line with those presented in Table 1.

To conclude, immigrants constitute a positive supply shock that reduces private earnings, whereas out-migrants represent a negative supply shock that increases private earnings. The outflow of migrants reduces the pressure faced by stayers by weakening competition in the labor market. These shocks are symmetric and suggest close substitutability across migrants and their skills. Finally, international flows smooth the business cycle by reducing or raising wages growth as migrants arrive or leave the country.

\section{Conclusions}

This paper presented evidence of how in- and out-migration rates of foreign-born individuals into the U.S. affected the state-level labor market in the first half of the 1900s.

The ability to distinguish between in- and outflows is a peculiarity of this analysis, which demonstrates that the impact of international flows was present during this period. Against the backdrop of a $2 \%$ average wage growth rate in real earnings at the time, this study showed that a $1 \%$ increase in the in-migration rate placed downward pressure on earnings (10\% change in earnings growth). Outflows, by contrast, relieved this pressure.

The negative (positive) relationship between inflows (outflows) and earnings is much smaller in the first half of the 1900s than for later periods (Card, 2001, Borjas, 2003). Yet, looking at changes in point estimates over time, 
such impact seems to increase, moving from a tenth of existing estimates during the 1930s and 1940s to a fourth in the 1950s.

To summarize, these findings suggest a rather weak but existent and increasing substitutability of migrants and natives at the state level during the early 1900s. Turning to outflows' behavior, if the results held for later periods, out-migration would be a possible area for policy intervention to smooth the business cycle. 


\section{A Appendix}

Table A.1: Summary Statistics at the State level, 1929-1957.

\begin{tabular}{lr}
\hline & Mean \\
\hline Per Capita Private Earnings (in 1985 dollars) & $3,164.839$ \\
& $(1,550.377)$ \\
Average Inflow & 3,628 \\
& $(9,286)$ \\
Average Outflow & 695 \\
& $(2,285)$ \\
\% in Mining & 2.433 \\
& $(3.814)$ \\
$\%$ in Agriculture & 19.520 \\
& $(13.451)$ \\
$\%$ in Manufacturing & 22.916 \\
& $(11.830)$ \\
\% in Personal Services & 6.552 \\
\% 0-14 Years Old & $(2.171)$ \\
$\%$ 14-44 Years Old & 29.285 \\
& $(3.829)$ \\
\% 44 Years Old & 72.540 \\
& $(21.582)$ \\
\% Black & 28.399 \\
& $(5.540)$ \\
$\mathrm{N}$ & 4.446 \\
\hline
\end{tabular}

Standard deviations in parentheses. 
Table A.2: First Stage Estimates: Determinants of In- and Out-Migration Rates

\begin{tabular}{|c|c|c|c|c|c|c|}
\hline & $i n_{i t}$ & out $_{i t}$ & $i n_{i t}$ & out $_{i t}$ & $i n_{i t}$ & out $_{i t}$ \\
\hline$i n_{i t-5}$ & $\begin{array}{c}0.655^{\text {*** }} \\
(0.041)\end{array}$ & $\begin{array}{l}0.350^{\text {*** }} \\
(0.065)\end{array}$ & $\begin{array}{l}0.616^{* * *} \\
(0.045)\end{array}$ & $\begin{array}{c}0.356^{* * *} \\
(0.067)\end{array}$ & $\begin{array}{l}0.591^{* * *} \\
(0.048)\end{array}$ & $\begin{array}{l}0.343^{\text {*** }} \\
(0.061)\end{array}$ \\
\hline out $_{i t-5}$ & $\begin{array}{l}0.155^{\text {*** }} \\
(0.039)\end{array}$ & $\begin{array}{l}0.511^{\text {*** }} \\
(0.052)\end{array}$ & $\begin{array}{c}0.142^{* * *} \\
(0.042)\end{array}$ & $\begin{array}{l}0.511^{* * *} \\
(0.048)\end{array}$ & $\begin{array}{l}0.152^{\text {*** }} \\
(0.041)\end{array}$ & $\begin{array}{c}0.481^{\text {*** }} \\
(0.047)\end{array}$ \\
\hline Time Fixed Effects & Yes & Yes & Yes & Yes & Yes & Yes \\
\hline Labor Market & No & No & Yes & Yes & Yes & Yes \\
\hline Demographics & No & No & No & No & Yes & Yes \\
\hline F-statistic & 65.700 & 45.900 & 56.69 & 49.53 & 46.57 & 42.430 \\
\hline p-value & 0.000 & 0.000 & 0.000 & 0.000 & 0.000 & 0.000 \\
\hline Underidentification & \multicolumn{2}{|c|}{6.786} & \multicolumn{2}{|c|}{5.975} & \multicolumn{2}{|c|}{5.870} \\
\hline $\mathrm{p}$-value & \multicolumn{2}{|c|}{0.009} & \multicolumn{2}{|c|}{0.014} & \multicolumn{2}{|c|}{0.015} \\
\hline Weak identification & \multicolumn{2}{|c|}{57.685} & \multicolumn{2}{|c|}{57.439} & \multicolumn{2}{|c|}{48.686} \\
\hline $10 \%$ maximal bias & \multicolumn{2}{|c|}{7.030} & \multicolumn{2}{|c|}{7.030} & \multicolumn{2}{|c|}{7.030} \\
\hline $\mathrm{N}$ & 766 & 766 & 766 & 766 & 766 & 766 \\
\hline
\end{tabular}

Significance levels: *: $10 \%,{ }^{* *}: 5 \%,{ }^{* * *}: 1 \%$.

Standard errors in parenthesis are robust for arbitrary heteroskedasticity and clustered at the state level. All regressions weighted by the inverse of the state population (in logs).

Sources: in and out measure in-migration and out-migration rates. See main text for details on the variables used. 
Table A.3: Robustness Checks: IV Effect of In- and Out-Migration Rates on Per Capita Private Earnings, at the State Level, 1929-1957.

\begin{tabular}{lccc}
\hline & $<1950$ & $\geq 1950$ & No Mid-Atlantic States \\
\hline in $_{\text {it }}$ & $-0.013^{* *}$ & $-0.059^{* *}$ & $-0.016^{* * *}$ \\
& $(0.006)$ & $(0.027)$ & $(0.005)$ \\
out $_{i t}$ & $0.011^{* *}$ & $0.051^{* *}$ & $0.013^{* * *}$ \\
& $(0.005)$ & $(0.025)$ & $(0.005)$ \\
Time Fixed Effects & Yes & Yes & Yes \\
Labor Market & Yes & Yes & Yes \\
Demographics & Yes & Yes & Yes \\
\hline $\mathrm{N}$ & & & 654 \\
\hline
\end{tabular}

Significance levels: ${ }^{*}: 10 \%,{ }^{* *}: 5 \%,{ }^{* * *}: 1 \%$.

Standard errors in parenthesis are robust for arbitrary heteroskedasticity and clustered at the state level.

Mid-Atlantic States Excluded: Delaware, Maryland, New Jersey, Pennsylvania, New York, Virginia, and West Virginia.

Sources: Inflows and outflows from the INS reports of 1929-1932, 1934-1936, 19431957. See main text for details on the variables used. 


\section{References}

Abramitzky, R., Boustan, L., Eriksson, K., 2012. A Nation of Immigrants: Assimilation and Economic Outcomes in the Age of Mass Migration. Working Paper 18011, National Bureau of Economic Research.

Bandiera, O., Rasul, I., Viarengo, M., 2010. The Making of Modern America: Migratory Flows in the Age of Mass Migration. Unpublished Manuscript.

Borjas, G. J., 2003. The Labor Demand Curve Is Downward Sloping: Reexamining the Impact of Immigration on the Labor Market. The Quarterly Journal of Economics 118 (4), 1335-1374.

Borjas, G. J., 2006. Native Internal Migration and the Labor Market Impact of Immigration. Journal of Human Resources 41 (2), 221-258.

Boustan, L. P., 2010. Was Postwar Suburbanization "White Flight"? Evidence from the Black Migration. The Quarterly Journal of Economics 125 (1), 417-443.

Boustan, L. P., Fishback, P. V., Kantor, S. E., 2010. The Effect of Internal Migration on Local Labor Markets: American Cities during the Great Depression. Journal of Labor Economics 28 (4), 719-746.

Card, D., 2001. Immigrant Inflows, Native Outflows, and the Local Labor Market Impacts of Higher Immigration. Journal of Labor Economics 19 (1), 22-64.

Ferrie, J. P., 1999. Yankeys Now: Immigrants in the Antebellum U.S. 1840-1860. Oxford University Press.

Ferrie, J. P., 2006. Internal Migration. In: Carter, S. B., Gartner, S. S., Haines, M. R., Olmstead, A. L., Sutch, R., Wright, G. (Eds.), Historical Statistics of the United States Millennial Edition Online. Cambridge University Press, pp. 1-489-1-494.

Goldin, C., 1994. The Political Economy of Immigration Restriction in the United States, 1890 to 1921. In: Goldin, C., Libecap, G. D. (Eds.), The Regulated Economy: A Historical Approach to Political Economy. NBER Chapters. National Bureau of Economic Research, pp. 223-258.

Haines, M. R., ICPSR, 2010. Historical, Demographic, Economic, and Social Data: The United States, 1790-2002. Inter-university Consortium for Political and Social Research (ICPSR) [distributor] 10.3886/ICPSR02896.

Lafortune, J., Tessada, J., February 2011. Smooth(er) Landing? The Dynamic Role of Networks in the Location and Occupational Choice of Immigrants, Unpublished Manuscript.

Ottaviano, G. I., Peri, G., 2012. Rethinking the Effects of Immigration on Wages. Journal of the European Economic Association 10 (1), 152-197.

U. S. Department of Labor, Bureau of Labor Statistics, 1984-05-11. Consumer price index, 1913-1992. 